\title{
Peculiarities of Organizational Economic Mechanism Development in correspondence with State Strategic Management in Russia
}

\author{
Liudmila P. Goncharenko \\ SRI Innovative economy \\ Plekhanov Russian University of Economics \\ Moscow, Russia \\ inn.invest@mail.ru
}

\author{
Sergey A. Sybachin \\ SRI Innovative economy \\ Plekhanov Russian University of Economics \\ Moscow, Russia \\ sybachin.sa@rea.ru
}

\author{
Mikhail V. Khachaturyan \\ Department of Theoretical management and business technologies \\ Plekhanov Russian University of Economics \\ Moscow, Russia \\ mike-hach@mail.ru
}

\begin{abstract}
In modern conditions, development of the organizational economic mechanism of state strategic management is a key element for ensuring sustainable development of Russia in the conditions of limited resources. The article considers basic approaches to the specific features of development of the organizational economic mechanism of state strategic management, formulates scientific approaches to the analysis of this state management mechanism and studies statistical materials which allow the authors to formulate their understanding of the issues related to the development of the organizational economic mechanism of strategic management in the structure of the state management system of Russia. Based on the conducted analysis, the authors draw their own conclusions regarding the directions for improvement and development of the organizational economic mechanism of strategic management in the state management system of Russia. The article presents the authors' own views on the strategic management structure in the state management system. Based on the analysis carried out in the article, some conclusions are formulated regarding the specific features of development of the organizational economic mechanism of strategic management in the state management system of Russia.
\end{abstract}

Keywords-organizational economic mechanism; strategic management; specific features; development; state management.

\section{INTRODUCTION}

The need to introduce strategic approaches to the state management system lies in the fact that in modern conditions an effective state management model provides a tool for developing and implementing long-term solutions to complex problems which are characterized by unclear boundaries, whereas their elimination or minimization may have a major impact on both national and global economy. Effective elaboration of strategic solutions is, in turn, a key criterion in assessing competence of public officials and government servants.

It should be noted that in the current conditions of forming global information space and developing integration processes, national governments, on the one hand, have fewer and fewer possibilities to control economic processes within national boundaries, and on the other, they have to confront ever increasing requirements to the quality of state management on the part of society.

\section{CONCEPT DEVELOPMENT}

The structure of the state management model includes two subdivisions:

- an organizational economic mechanism of the national economic system management;

- a control mechanism of the national economic system.

In the conditions of economic instability, the question of establishing the processes of functioning of these subdivisions becomes particularly important.

It is obvious that this issue of forming a new model of the organizational economic mechanism of state strategic management relates to determining specific features, structure and effectiveness of state influence on the economic system rather than to determining the role of the state in the economy. In the $19^{\text {th }}$ century, Karl Marx defined the state as "the executive committee of the bourgeoisie" [1]. As applied to that period of time, this definition was to a certain extent justified. In modern conditions, however, the state is the main tool for implementing joint efforts of society to achieve the goals of socioeconomic development. 
It should be noted that in modern conditions, any country's government is a complex organization, which is particularly true for Russia. Effectiveness standards are not always clear and management processes are dispersed over a number of areas. At the same time, the government is to act as a relatively integral structure to ensure stability of the country's economic system.

It is obvious, however, that in modern conditions neither the government nor any other state agency represents universal power. Acting alone, they are not able to form the most preferred and effective behavioral model of economic entities. They can at best guide these entities in the right direction. In this context, drawing a difference between the notions of a normative country and a developed country appears to be relevant.

The former have limitations in terms of interest in and capability for economic strategy development, as well as in terms of the range of political and organizational tools for its implementation.

The latter possess all required tools to approach management of economic processes in a strategic and purposeful way. [2].

However, it is important to note that neither group exists in real state management systems in its pure form. Each state management system has features of both 'normative' and 'developed' countries. Therefore, determining the dominant features in the model under study becomes a focal point.

The main objective of nation-level strategic management systems is to determine rules and guidelines for economic activity within the national territory. Accomplishing this task will lead to a considerable number of economic entities endeavoring to find a way to influence government decisions to their advantage [15].

Obviously, an in-depth scientific analysis of company behavior under the influence of government decisions and attempts of private organizations to influence government decisions is critical to increasing effectiveness of nation-level strategic management systems.

Thus, it can be concluded that the long-term government behavior is a real and, most likely, the best indicator to analyze the content of the national economic strategy.

\section{RESEARCH METHODS}

The state strategy of national economic management can be defined as a behavioral or decision-making model within the system of state economic regulation, which defines tasks, generates policies and plans, determines activities of authorities and agencies, participates in their implementation processes, and assesses performance and effectiveness of activities. Therefore, nation-level strategic management is the result of deliberate activities of state agencies.

An important feature in the implementation of state strategic management goals and targets in modern conditions is the presence of four different types of ownership:
1. State ownership;
2. Communal non-state ownership;
3. Corporate ownership;

4. Private ownership.

A key difference between these types of ownership is not only their association with regulatory mechanisms of public or private law, but also the goal for which property is used:

- If property is used for the goal of profit maximization, this property falls under the category of personal ownership;

- If the goal is to pursue state or public interests, the property falls under the category of state or communal ownership;

- If the goal is to protect group interests in business, the property belongs to the category of corporate ownership [11, 12].

Although the strategy implementation tools are the same for both private organizations and the state management system, there are important differences in the strategic management development process between private organizations and the state management system.

Essentially, the state strategic management process starts by formulating the goal, which has to be formed with account for capabilities of the state-managed entity, as well as economic limitations and capabilities of the national economic system. If these aspects have been taken into consideration, the state strategy may be carried out by means of regular adjustment of resource volumes and structural and workforce variables $[13,14]$.

However, this state strategic management model requires that state servants and government officials are responsible for developing and testing strategy implementation alternatives.

In view of this, it is important to note that in modern conditions, there is an increasing necessity for public officials and government servants to develop or acquire new skills and performance areas. By studying a wide range of management systems in the state management system, one can see that the state structures where a well-developed system of tactical and operational management is in place to assist them in coping with external and internal cognitive factors have considerable limitations in respect of strategic development. [9, 10].

Such systems result from vertical specialization among executive officials who:

- being in contact with technology and markets are normally capable of formulating product and market strategies;

- $\quad$ ensure the general course of activity, select government officials to be in charge of strategy and manage their behavior by changing the magnitude and structure of incentives;

- have a better understanding of operational environment at the low operational level of state management and, at the same time, better meet requirements specified for government servants $[4,5$, 6].

It is important to note that these three layers of state strategic management constitute a system where a decision is processed in such a way that the state governance system as a whole constantly changes in accordance with the defined goal. 
Moreover, the state management strategy development process consists of three interacting elements:

- Operational strategy;

- Organizational logic at the tactical management level;

- Political or interpersonal logic at the strategic level of state management $[7,8]$.

In using this kind of model, all three management levels are actually involved at all stages of the state strategy development process. The key point of strategy design and system operation is that strategy formulation and implementation are aimed to accomplish the overall goals of the national economic system development.

\section{RESULTS OF THE RESEARCH}

The key elements in improving the quality of management decisions within the organizational economic mechanism of state strategic management are:

- $\quad$ Creating and developing a communication system on the basis of high-quality information flows;

- Introducing modern analysis and consultation tools to the management decision elaboration and support system;

- A well-balanced set of state strategic management elements.

In modern conditions, it becomes obvious that a dynamic balance is required between three operational elements of the organizational economic mechanism of state strategic management to achieve its optimal performance:

- tools to determine direction and goals of impact;

- $\quad$ level of autonomy of structural elements;

- $\quad$ specific conditions for implementation of mechanisms and tools to control effectiveness.

An important aspect in the development of the organizational economic mechanism of state strategic management of state assets and partially government-owned joint stock companies is assessment of financial and economic performance of such organizations by state agencies.

As of the end of 2015, the financial and economic performance of government-owned joint stock companies was analyzed by Rosimushchestvo without considering the performance of joint stock companies which were under restructuring, under liquidation, not involved in financial and economic activities, as well as those where bankruptcy procedures had been instituted based on court decisions (information on the number of such organizations is given in section 1 of the report), based on the data of accounting reports submitted by state-owned companies in accordance with the Russian accounting standards [3].

According to the available data, the total amount of revenue of state-owned companies as of the end of 2015 was 12751 billion rubles, including 12345 billion rubles (or 97\% of the total revenue of state-owned companies) earned by 40 joint stock companies (hereinafter called 'major joint stock companies'), with each having a balance sheet total of over 50 billion rubles [3].

As of the end of 2015, the main share of revenue of the major join stock companies comes from two state-owned companies: Gazprom PJSC (4 334 billion rubles) and Rosneft NC PJSC (3831 billion rubles), which totals up to 8165 billion rubles or $66 \%$ of the total amount of revenue of the major joint stock companies (Table 1) [3].

TABLE I. REVENUE OF MAJOR JOINT STOCK COMPANIES

\begin{tabular}{|l|c|c|}
\hline Joint Stock Company & $\begin{array}{c}\text { Revenue in 2015, } \\
\text { million rubles }\end{array}$ & $\begin{array}{c}\text { Percentage of total } \\
\text { revenue of major joint } \\
\text { stock companies, \% }\end{array}$ \\
\hline Gazprom PJSC & 4334293 & 35 \\
\hline Rosneft NC PJSC & 3831095 & 31 \\
\hline $\begin{array}{l}\text { Total for two major } \\
\text { joint stock companies }\end{array}$ & 8165388 & 66 \\
\hline $\begin{array}{l}\text { Total for two major } \\
\text { joint stock companies } \\
\text { and other joint stock } \\
\text { companies }\end{array}$ & 12344807 & 100 \\
\hline
\end{tabular}

The amount of revenue of the major joint stock companies is critical to the overall performance result of state-owned companies in different sectors of the Russian economy. The dynamic analysis of key financial and economic performance indicators has been carried out for this category of joint stock companies. As of the end of 2015, the following tendencies have been revealed by the analysis of financial and economic performance of state-owned companies:

1. The aggregate balance sheet total of the major joint stock companies as of the end of 2015 was 46363 billion rubles, $13 \%$ up compared to the previous year (Table 2).

The main share of the balance sheet total of the major joint stock companies is accounted for by seven state-owned companies amounting to 39695 billion rubles or $86 \%$ of the aggregate balance sheet total of the major joint stock companies as of the end of 2015:

- Gazprom PJSC - 12981 billion rubles;

- $\quad$ Rosneft NC PJSC- 9450 billion rubles;

- $\quad$ VTB Bank (PJSC) - 9395 billion rubles;

- ROSNEFTEGAZ JSC - 2835 billion rubles;

- Rosselkhozbank JSC - 2511 billion rubles;

- $\quad$ FSK UES PJSC - 1268 billion rubles;

- $\quad$ AK Transneft PJSC - 1256 billion rubles.

The balance sheet total of other major joint stock companies represents 6668 billion rubles or $14 \%$ of the aggregate balance sheet total of the major joint stock companies [3]. 
TABLE II. BALANCE SHEET TOTAL OF MAJOR JOINT STOCK COMPANIES

\begin{tabular}{|c|c|c|c|c|}
\hline Joint stock company & $\begin{array}{l}\text { Balance } \\
\text { sheet } \\
\text { total for } \\
2015 \text {, } \\
\text { mln }\end{array}$ & $\begin{array}{c}\text { Balance } \\
\text { sheet } \\
\text { total for } \\
2014 \text {, } \\
\text { mln. }\end{array}$ & $\begin{array}{c}\text { Balance } \\
\text { sheet } \\
\text { total } \\
\text { change } \\
\text { for } 2015 \text {, } \\
\%\end{array}$ & $\begin{array}{c}\text { JSC's } \\
\text { share in } \\
\text { the } \\
\text { aggregate } \\
\text { balance } \\
\text { sheet } \\
\text { total for } \\
\text { 2015, \% }\end{array}$ \\
\hline Gazprom PJSC & $\begin{array}{c}12981 \\
248\end{array}$ & $\begin{array}{c}12249 \\
735\end{array}$ & 6 & 28 \\
\hline Rosneft NC PJSC & $\begin{array}{c}9449 \\
874\end{array}$ & $\begin{array}{c}7787 \\
727\end{array}$ & 21 & 20 \\
\hline VTB Bank (PJSC) & $\begin{array}{c}9394 \\
601\end{array}$ & $\begin{array}{c}8295 \\
424\end{array}$ & 13 & 20 \\
\hline ROSNEFTEGAZ JSC & $\begin{array}{c}2834 \\
815\end{array}$ & $\begin{array}{c}2256 \\
264\end{array}$ & 26 & 6 \\
\hline Rosselkhozbank JSC & $\begin{array}{c}2510 \\
940\end{array}$ & $\begin{array}{c}2067 \\
492\end{array}$ & 21 & 5 \\
\hline FSK UES PJSC & $\begin{array}{c}1268 \\
301\end{array}$ & $\begin{array}{c}1231 \\
217 \\
\end{array}$ & 3 & 3 \\
\hline AK Transneft PJSC & $\begin{array}{c}1255 \\
562\end{array}$ & $\begin{array}{c}1128 \\
408\end{array}$ & 11 & 3 \\
\hline $\begin{array}{l}\text { Total for seven major } \\
\text { joint stock companies }\end{array}$ & $\begin{array}{c}39695 \\
341\end{array}$ & $\begin{array}{c}35016 \\
268\end{array}$ & 13 & 86 \\
\hline $\begin{array}{l}\text { Other major joint } \\
\text { stock companies }\end{array}$ & $\begin{array}{c}6667 \\
709\end{array}$ & $\begin{array}{c}5842 \\
923\end{array}$ & 14 & 14 \\
\hline $\begin{array}{l}\text { Total for seven major } \\
\text { joint stock companies } \\
\text { and other major joint } \\
\text { stock companies }\end{array}$ & $\begin{array}{c}46363 \\
051\end{array}$ & $\begin{array}{c}40859 \\
190\end{array}$ & 13 & 100 \\
\hline
\end{tabular}

It should be noted that the increase in the balance sheet total of the major joint stock companies is due to assets growth, as well as reevaluation of assets valued in foreign currency.

2. The total amount of revenue of the major joint stock companies as of the end of 2015 has amounted to 12345 billion rubles, $2 \%$ up compared to the previous year (Table 3 ).

The main share of revenue coming from the major joint stock companies is accounted for by two state-owned companies, amounting to 8165 billion rubles or $66 \%$ of the total amount of revenue of the major joint stock companies as of the end of 2015 :

- $\quad$ Gazprom PJSC - 4334 billion rubles;

- $\quad$ Rosneft NC PJSC - 3831 billion rubles.

The growth in revenue of the other major joint stock companies was $10 \%$ or 4179 billion rubles (i.e. $34 \%$ of the total revenue of the major joint stock companies for 2015) [3].

3 . The net profit of the major joint stock companies as of the end of 2015 amounted to 892 billion rubles, $6 \%$ down compared to the previous year (Table 4).

The main share of the net profit coming from the major joint stock companies is accounted for by three state-owned companies amounting to 792 billion rubles or $89 \%$ of the total net profit amount of the major joint stock companies as of the end of 2015:

- Gazprom PJSC - 404 billion rubles;

- $\quad$ Rosneft NC PJSC - 239 billion rubles;

- ROSNEFTEGAZ JSC - 149 billion rubles.

The net profit reduction at Rosneft NC PJSC and ROSNEFTEGAZ JSC was due to a decreased (net) revenue from sales of goods, products, work and services during the reporting period.

TABLE III. GROWTH IN REVENUE OF MAJOR JSCS

\begin{tabular}{|l|c|c|c|c|}
\hline \multicolumn{1}{|l}{$\begin{array}{l}\text { Joint stock } \\
\text { company }\end{array}$} & $\begin{array}{c}\text { Revenue } \\
\text { for 2015, } \\
\text { million } \\
\text { rubles }\end{array}$ & $\begin{array}{c}\text { Revenue } \\
\text { for 2014, } \\
\text { million } \\
\text { rubles }\end{array}$ & $\begin{array}{c}\text { Change in } \\
\text { revenue } \\
\text { for 2015, } \\
\text { \% }\end{array}$ & $\begin{array}{c}\text { Share of } \\
\text { revenue } \\
\text { for 2015 } \\
\text { in the } \\
\text { total } \\
\text { amount of } \\
\text { revenue } \\
\text { of major } \\
\text { JSCs, \% }\end{array}$ \\
\hline $\begin{array}{l}\text { Gazprom } \\
\text { PJSC }\end{array}$ & 4334293 & 3990280 & 9 & 35 \\
\hline $\begin{array}{l}\text { Rosneft NC } \\
\text { PJSC }\end{array}$ & 3831095 & 4299680 & -11 & 31 \\
\hline $\begin{array}{l}\text { Total for two } \\
\text { major joint } \\
\text { stock } \\
\text { companies }\end{array}$ & 8165388 & 8289960 & -2 & 66 \\
\hline $\begin{array}{l}\text { Other major } \\
\text { joint stock } \\
\text { companies }\end{array}$ & 4179419 & 3813274 & 10 & 34 \\
\hline $\begin{array}{l}\text { Total for two } \\
\text { major joint } \\
\text { stock } \\
\text { companies } \\
\text { and other } \\
\text { major joint } \\
\text { stock } \\
\text { companies }\end{array}$ & 12344807 & 12103234 & 2 & 100 \\
\hline
\end{tabular}

The net profit indicator of the other major joint stock companies grew substantially in 2015 to 100 billion rubles, whereas in 2014 the net profit of the other major joint stock companies amounted to 75 billion rubles [3]

TABLE IV. NET PROFIT OF MAJOR JSCS

\begin{tabular}{|c|c|c|c|c|}
\hline $\begin{array}{c}\text { Joint stock } \\
\text { company }\end{array}$ & $\begin{array}{c}\text { Net } \\
\text { profit } \\
\text { for } \\
2015, \\
\text { mln } \\
\text { rubles }\end{array}$ & $\begin{array}{c}\text { Net } \\
\text { profit } \\
\text { for } \\
2014, \\
\text { mln } \\
\text { rubles }\end{array}$ & $\begin{array}{c}\text { Net } \\
\text { profit } \\
\text { change } \\
\text { for } 2015 \text {, } \\
\%\end{array}$ & $\begin{array}{l}\text { Share of } \\
\text { revenue for } \\
2015 \text { in the } \\
\text { total amount } \\
\text { of net profit } \\
\text { of major } \\
\text { JSCs, \% }\end{array}$ \\
\hline Gazprom PJSC & $\begin{array}{l}403 \\
523\end{array}$ & $\begin{array}{l}188 \\
980\end{array}$ & 114 & 45 \\
\hline Rosneft NC PJSC & $\begin{array}{l}239 \\
413\end{array}$ & $\begin{array}{l}501 \\
324\end{array}$ & -52 & 27 \\
\hline $\begin{array}{l}\text { ROSNEFTEGAZ } \\
\text { JSC }\end{array}$ & $\begin{array}{l}149 \\
360\end{array}$ & $\begin{array}{l}184 \\
031\end{array}$ & -19 & 17 \\
\hline $\begin{array}{l}\text { Total for three } \\
\text { major joint stock } \\
\text { companies }\end{array}$ & $\begin{array}{l}792 \\
296\end{array}$ & $\begin{array}{l}874 \\
336\end{array}$ & -9 & 89 \\
\hline $\begin{array}{l}\text { Other major joint } \\
\text { stock companies }\end{array}$ & 99719 & 75113 & 33 & 11 \\
\hline $\begin{array}{l}\text { Total for three } \\
\text { major joint stock } \\
\text { companies and } \\
\text { other major joint } \\
\text { stock companies }\end{array}$ & $\begin{array}{l}892 \\
015\end{array}$ & $\begin{array}{l}949 \\
449\end{array}$ & -6 & 100 \\
\hline
\end{tabular}

The dynamics of the revenue and net profit indicators of the major joint stock companies for 2015 and 2014 is shown in Figure 6. 
The growing geopolitical tension and volatility in the capital markets in 2015 led to more costly funding and increased interest costs.

It is also necessary to note that the 2015 financial results were seriously affected by the sanctions imposed in 2014 [3].

Another aspect in the assessment of effectiveness of state property use and financial and economic activities of stateowned companies is forecasting federal budget revenues from the activities of these organizations in the form of dividends, which is shown in Figure 1.

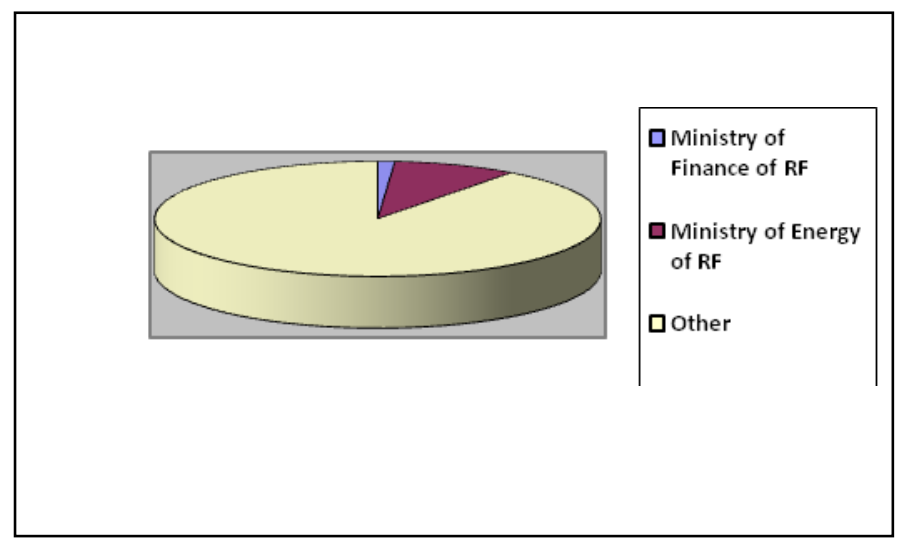

Fig. 1. Forecasting federal budget revenues in the form of dividends as of the end of 2015 from Spetsperechnya JSC. Source: [3]

To assess effectiveness of state property use and, consequently, the modern state of the organizational economic mechanism of state strategic management, the authors find it necessary to provide revenue data for major state-owned joint stock companies in 2016.

Thus, as of the end of 2016:

The total revenue of Gazprom PJSC amounted to 6111000 million rubles, or $11 \%$ up as compared to the same 2014 indicator [16];

The net profit of Rosneft NC PJSC amounted to 181000000 million rubles, or $49 \%$ down as compared to the same 2015 indicator [17].

Basically, it should be noted that the revenue and net profit growth dynamics of the two largest oil and gas corporations of Russia is oppositely directed: Gazprom PJSC shows revenue growth, whereas the net profit of Rosneft NC PJSC has more than halved.

Obviously, the above indicators are influenced by negative external factors, such as a decrease in the oil price, economic sanctions, etc.

Therefore, the obvious conclusion is that the existing organizational economic mechanism of state strategic management in Russia needs to be improved.

For the purpose of improving corporate management at joint stock companies and ensuring management effectiveness and transparency by introducing unified dividend policy approaches, Rosimushchestvo is working on the implementation of the key dividend policy principles described in the Methodology Guidelines on the development of dividend policy at joint stock companies approved by Rosimushchestvo's Resolution No. 524 of 29.12.2014 [3].
The Methodology Guidelines developed by Rosimushchestvo facilitate transparency of the dividend payment (announcement) decision-making mechanism as well as the procedure for their payment to shareholders and all stakeholders [3].

The Methodology Guidelines describe key factors related to the development and approval of a dividend policy at a joint stock company, such as:

- $\quad$ Dividend policy principles;

- Determining the amount of dividends and the dividend payment (announcement) decision-making procedure;

- Persons entitled to receive dividends and dividend payment procedure;

- Dividend payment restrictions;

- Informing shareholders and other stakeholders on the company's dividend policy;

- Liability for incomplete and/or untimely dividend payment [3].

The analysis of dividend policies at joint stock companies as of the end of 2015 points to a steady trend towards exceeding the stipulated budgetary assignment (34\% above target as of the end of 2015).

Alongside this, Rosimushchestvo is planning to continue improving the process of formation and collection of part of state-owned companies' net profit to the federal budget from dividend payment by prescribing a clear and transparent action algorithm recommended for use by state-owned companies with a view to improving their management quality [3].

\section{CONCLUSION}

As mentioned above, the quality of state strategic management in modern conditions is determined by the capability to form and develop key competences of public officials and government servants.

Obviously, this capability consists in the ability of the organizational economic mechanism of state strategic management:

To form and implement a set of goodquality long-term management decisions;

- To create and disseminate knowledge on state strategic management directions;

- $\quad$ To effectively implement the management decisions made;

- $\quad$ To act as an intermediary between business structures with competing interests.

The obvious conclusion is that in modern conditions the introduction and implementation of strategic management mechanisms in the state management system is critical to improving its quality and, consequently, determines the country's global competitive advantage.

This article was prepared as part of the project section of the government contract as requested by the Ministry of Education and Science of the Russian Federation on the subject formulated as 'Development of Methodological Principles and Organizational Economic Mechanism of 
Strategic Management of Economic Security in Russia'. (Assignment No. 26.3913.2017/ПЧ).

\section{References}

[1] K. Marx, F. Engels, Capital. Vol. 1. Moscow: Politizdat. 1956.

[2] Mikhail, V. Khachaturyan, "Organizational-economic mechanism of formation and realization of the industrial policy within the framework of the CMEA and the EU: experience and prospects for Russia". International Business Management, Vol. 10, № 14, p. 2677, 2016.

[3] Report on the management of shares of open joint stock companies in federal ownership and using the special right of the Russian Federation to participate in the management of open joint stock companies ('gold share') as of the end of 2015, The Ministry of Economic Development of Russia, Rosimushchestvo, 2015.

[4] A. Zimin, V. Otto, N. Filimonova, R. Fedosova, Y. Kuznetsov, "New type of regions in the innovation economy", Advanced Science, Vol. 22 (8), pp. 2002-2006 Letters, 2016.

[5] L.P. Goncharenko, S.A. Filin, E.E. Nalesnaya, "Strategic risk management in innovative metallurgical". Steel in Translation, 46 (1), pp. 42-44, 2016.
[6] C.E. Lindblom, "Bargaining? The hidden hand in government," RM1434-RC, Rand Corporation, February 22, 2015.

[7] C.E. Lindblom, "The science of muddling through," Public administration review, vol. 19, Spring, 2015.

[8] D. Truman, The governmental process. New York, 2015.

[9] C.E. Lindblom, D. Braybrooke, A strategy of decision. Glencoe, IL, 2016.

[10] A. Wildavsky, The politics of the budgetary process. Boston, 2014.

[11]W. Sayer, H. Kaufman, Governing New York city. New York, 2015.

[12]V.A. Thompson, The regulatory process in OPA rationing. New York, 2015

[13]H.A. Simon, Administrative Behavior. McMillan, New York, 2014.

[14]R. Neustadt, Presidential power. Wiley, New York, 2014.

[15]G.T. Allison, The essence of decision. Little, Brown Co., Boston, MA, 2014.

[16] The data is based on the materials of the Gazprom PJSC official website www.gazprom.ru.

[17]The data is based on the materials of the Rosneft NC PJSC official website - www.rosneft.ru. 